移植後難治性サイトメガロウイルス䯣膜脳炎に対する非完全ヒト化免疫グロブ リン能避注療法の有効性と問題点

大中貴史, 北川智也, 片山映樹, 米澤昭仁

小倉記念病院血液内科

症例は 53 歳女性。 2012 年発症した急性型成人 T 細胞白血病（ATL）にてモガムリズマブ投与後，部分寛解の状態 で骨骾非破壊的臍帯血移植を実施した。Day 22 に生着を確認したが，同時に移植片対宿主病（GVHD）が出現した。 プレドニゾロンの投与開始後, サイトメガロウイルス脳炎を発症した。抗ウイルス剤投与も無効で, 非完全ヒト型免 疫グロブリン製剂を髄腔内投与した。一過性に症状の改善及び䯣液ウイルス量の低下を認めた。同治療は一時的には 有効であるものの，さらなる検討が必要である。（日本造血細胞移植学会誌 $6(4): 162-165,2017$.

\section{緒言}

同種造血幹細胞移植経過中に発症する重症中枢神経系感 染症は生命予後に極めて悪い影響を与えるとともに，後遺 症のため日常生活動作に悪影響を与えることも多い。今 回，成人 $\mathrm{T}$ 細胞白血病（adult T-cell leukemia, ATL）の臍帯 血移植 (cord blood transplantation) 実施後, 特異的薬物療法 のみで制御困難なサイトメガロウイルス (cytomegalovirus, CMV) 脳炎に非完全ヒト型免疫グロブリン製剤髄注療法を 実施し, 一時的な症状の改善およびウイルス感染の制御を 認めたため, 同治療の問題点を含め報告する。

\section{症例}

患者：53 歳，女性。

主訴：全身僚㐭感，食思不振。

既往歴：虫垂炎。

現病歴：生来健康。2012 年 12 月に全身倦㤐感, 食思不 振, 高カルシウム血症を契機に急性型 ATL と診断。多剂併 用化学療法 (EPOCH 療法) 1 コースを実施したが治療効果 が得られず。モガムリズマブ 8 コース実施後の病勢は部分 寛解状態であり，モガムリズマブ最終治療から 1 か月間の 間隔にて同種臍帯血移植目的に入院となった。

入院時現症：ECOG Performance status 2, 発熱なし, 眼瞼
結膜：貧血なし, 眼球結膜：黄疸なし。表在リンパ節：腫 脹なし。胸腹部：異常なし。肝脾腫なし。

入院時検査所見：白血球数 $9,100 / \mu \mathrm{L}$ （ATL 細胞 $2 \% ）$ と 少数ながら ATL 細胞の出現を認めた。貧血および血小板減 少は認めず。LDH は $317 \mathrm{IU} / \mathrm{L}, \mathrm{sIL}-2 \mathrm{R}$ は 1,370 U/mL とい ずれも軽度の上昇にとどまった。

入院後経過 : HLA-A および B 座の血清 2 座不一致の臍帯 血を選択した。細胞数は $3.0 \times 10^{7} \mathrm{cells} /$ 患者体重（CD34 陽 性細胞数 $0.47 \times 10^{5}$ cells/患者体重）と十分量で，かつ HLA 抗体は有していないことを確認したうえ, フルダラビン $125 \mathrm{mg} / \mathrm{m}^{2}$, メルファラン $80 \mathrm{mg} / \mathrm{m}^{2}$, 全身放射線照射 $4 \mathrm{~Gy}$ の前処置後臍带血移植を実施した。移植片対宿主病 (GVHD) の予防は夕クロリムスとミコフェノール酸モフェ チルの投与を実施した。移植後 22 日目に生着を認めたが, 同時期に嘔気と心窩部痛，下痢が出現。上下部内視鏡検査 および生検検査にて急性 GVHD と診断。この時点で CMV 腸炎を示唆する内視鏡所見および組織学的に封入体などは 認められなかった。急性 GVHD は, 腸管 stage 4 まで悪化 したためプレドニゾロン $1 \mathrm{mg} / \mathrm{kg}$ の投与を開始。下痢の改 善が得られたものの移植後 90 日目に突然の見当識障害が 出現した。MRI 検査にて辺縁系脳炎の所見は認めなかった が, 大脳半球白質および両側脳室周囲, 脳梁に多発高信号 を認めた (Figure 1)。髄液所見では細胞数は単核球 42 cells/ $3 \mathrm{~mm}^{3}$, 蛋白 $85 \mathrm{mg} / \mathrm{dL}$, 糖 $52 \mathrm{mg} / \mathrm{dL}$ と単核球優位の細胞増

Submitted November 17, 2016; Accepted June 25, 2017; Published online, October 16, 2017. (Handling Editor: Naoyuki Uchida, Toranomon Hospital)

Key words: ATL, cord blood transplantation, cytomegaloviral meningo-encephalitis, intrathecal immnunoglubulin

Correspondence: Takashi Onaka, Kokura Memorial Hospital, Dept of hematology, 3-2-1 Asano, kokurakita-ku, kitakyushu, 802-8555, Japan. E-mail: oonaka-t@kokurakinen.or.jp dx.doi.org/10.7889/hct-16-032 (C) The Japan Society for Hematopoietic Cell Transplantation. 
Figure 1. Brain MRI (diffusion weighted image). Brain MRI (diffusion weighted image) at onset of consciousness loss. Disseminated small high intensity area were existed.
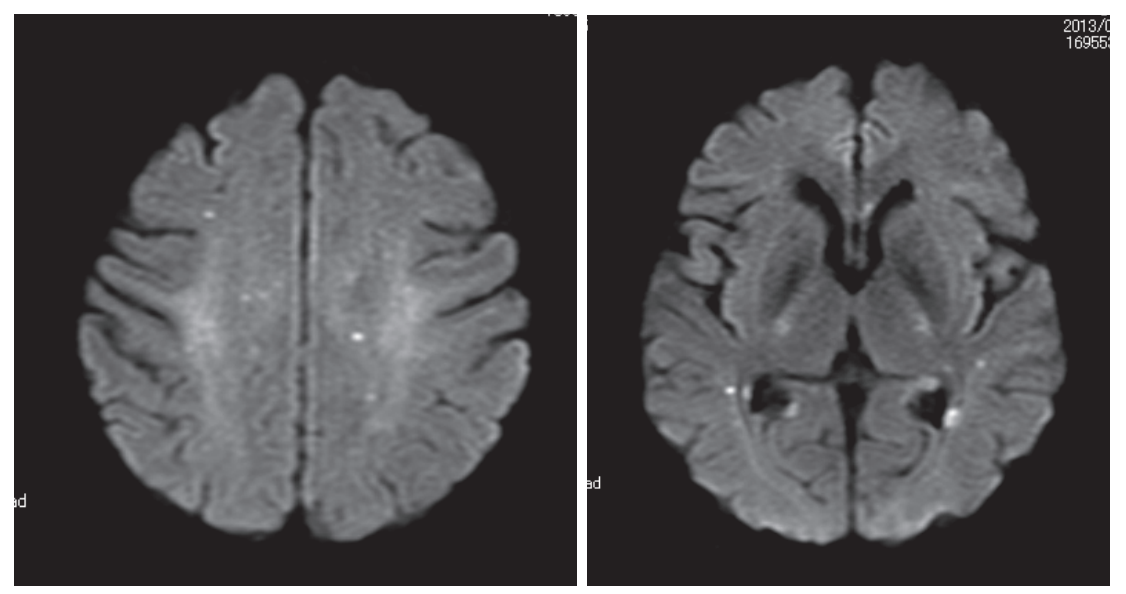

Globulin 500mg intrathecal infusion
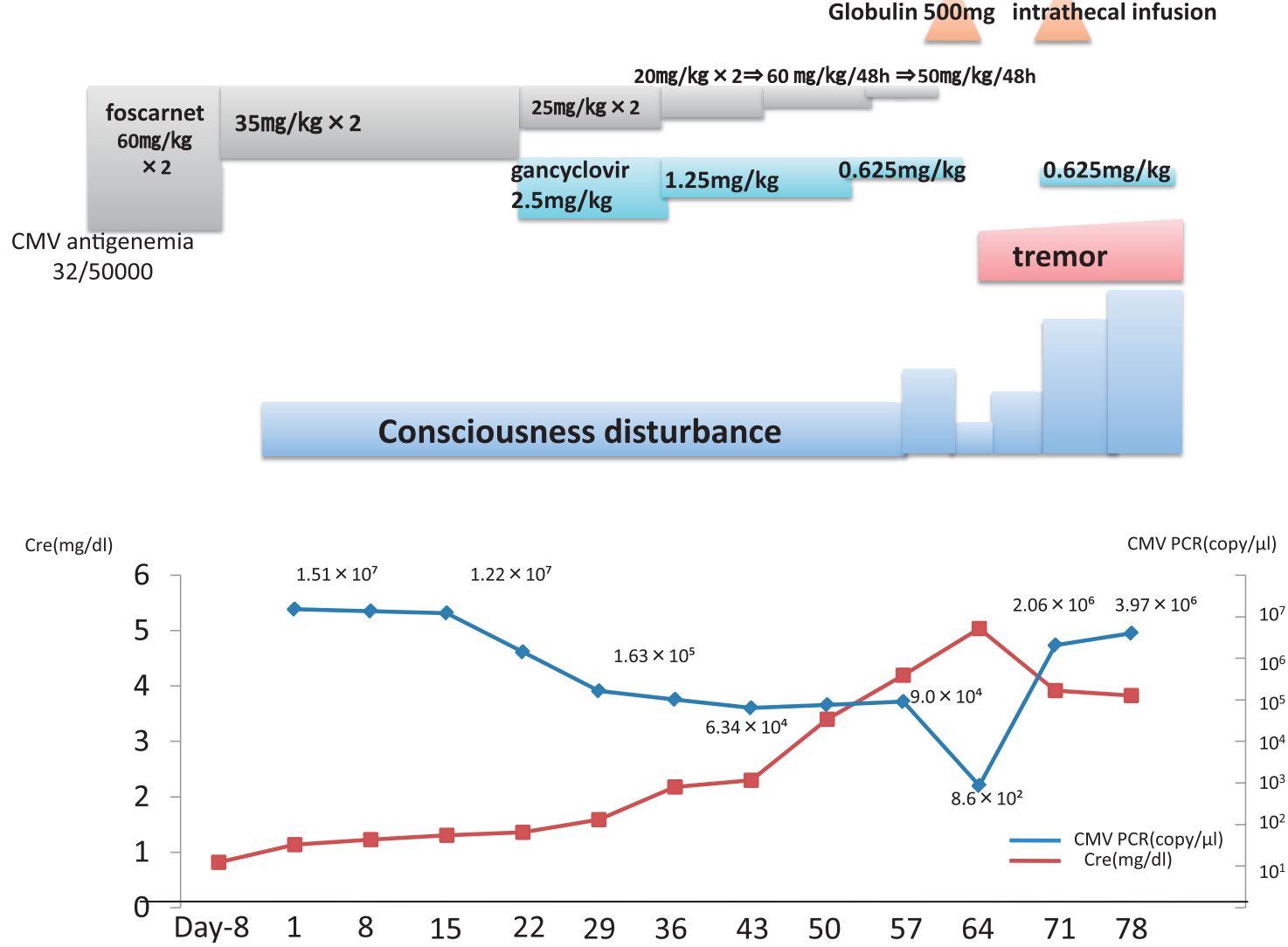

Figure 2. Clinical course. The anti-viral drugs were not effective, and the patient was treated with intrathecal administration of non-complete human immunoglobulin. After the treatment, viral load in cerebrospinal fluid and symptoms were transiently improved.

加を認め，髄液糖の低下は認めず，細胞診および細胞表面 マーカー解析にて再発は否定され, 髄液細菌培養検査は陰 性, ウイルス PCR 検査では HHV-6 が $1.62 \times 10^{3} \mathrm{copy} / \mathrm{mL}$ と 少数陽性となったものの, CMV が $1.51 \times 10^{7} \mathrm{copy} / \mathrm{mL}$ と高 值陽性と判明し CMV 脳炎と診断した。サイトメガロウイ ルス抗原血症に対してホスカルネットの通常量 (120 mg/ $\mathrm{kg}$ ）先制攻撃治療中に発症し， かつ投与 1 週間において
eGFR は $76 \mathrm{~mL} / \mathrm{min} / 1.73 \mathrm{~m}^{2}$ から $49 \mathrm{~mL} / \mathrm{min} / 1.73 \mathrm{~m}^{2}$ と腎機 能障害が出現し増悪したため, ホスカルネットを腎機能障 害の進行に合わせて減量しつつ継続, 次いでガンシクロビ ルの併用療法を実施したが, 最終的に腎機能障害のため両 者継続困難となった。移植後の重症 CMV 脳炎に対し, 診 断確定 58 日目より当院生命倫理委員会での承認を得たの ちに，髄腔内投与が保険適応となっている非完全ヒト型免 
疫グロブリン製剂 $500 \mathrm{mg}$ 䯣腔内投与を実施した。それまで 困難であった，静坐不能や日時の認識低下，生年月日の認 識，尿失禁が投与数日で改善を認め, 髄液ウイルス量も減 少したが，2 回目の投与後より，再び見当識障害および不 穏が出現。髄液 CMV ウイルス量も増加し, 脳炎の改善に は至らず，移植後 177 日目（サイトメガロウイルス髄膜脳 炎診断 87 病日）に永眠された。（Figure 2）。

\section{考察}

同種移植後 CMV 感染は，肺炎や網膜炎，脳炎などを認 めしばしば致死的である。CMV 脳炎を発症した場合にお いても抗ウイルス療法が実施されるが, 後遺症の発現する 可能性が高く早期治療介入を行うことが重要である。免疫 グロブリン製剤は，オプソニン効果による食細胞の貪食能 立進, ADCC (antibody dependent cell mediated cytotoxicity)

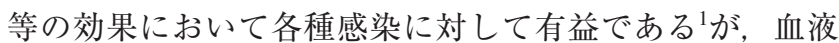
脳関門の影響から静脈内投与においては，十分な髄腔内移 行が得られない2とされる。一方, 中枢神経感染症に対する 免疫グロブリン髄注療法が数報報告され ${ }^{2-5}$, 一定の治療効 果が示されている。我々は髄注可能な非完全ヒト型免疫グ ロブリン製剤を使用，効果は得られたものの一過性であっ た。自験例において治療効果が限定的であった理由として 本感染が脳炎まで至っていたこと，投与開始時期およびグ ロブリン製剤の選択が挙げられる。とくに投与時期に関し ては CMV 脳炎診断確定からグロブリン製剤䯣腔内投与ま で58日間経過しており, 副作用により十分量の抗ウイルス 剂投与が出来なかったことが問題と考えられる。非完全ヒ 卜化免疫グロブリン髄腔内投与にて明らかな急性期副作用 は認められなかったことから, 診断早期に抗ウイルス剂と 併用することが有益であると考えられた。一方, 非完全ヒ ト化免疫グロブリン製剤髄腔内投与がサイトメガロウイル
又䯣膜脳炎に対しての有用であることは既報において明確 ではないことが投与に際しての最大の問題である。また， 非完全ヒト化免疫グロブリン製剤は Fc 領域を欠いており, 副作用の軽減が期待できるが感染に対してはオプソニン活 性が期待できないこと，NK 細胞による抗体依存性細胞傷 害活性（ADCC 活性）を期待できず，さらに補体がない髄 液中では補体依存性細胞傷害活性（CDC 活性）も期待しつ らいことなど, 問題点が多く存在している。今後は完全ヒ 卜型免疫グロブリン製剤髄腔内投与を用いた治療の有用性 の検討に加え，グロブリンの反応に必要な補体やエフェク ター細胞の追加投与などさらなる検討をする必要があると 考えられる。

\section{利益相反の開示}

本論文発表内容に関連して特に申告なし。

\section{文献}

1. 松田孝二, 村岡宏江，鈴木真言，池田文昭．多剂耐性緑 膿菌に対する好中球の貪食能における免疫グロブリン製 剂の効果. 診療と新薬. 2012; 8: 1055-1059.

2. 西澤英二, 山本弘之，河野拓司，鎌田健一，髄膜炎に対 する免疫グロブリン製剤の髄腔内投与に関する臨床的検 討. 治療. 1988; 4: 996-1002.

3. Etziomi A, Benderly A, Pollack S. Immunoglobulin administration into cerebral subarachnoid space in a child with hypogammaglobulinemia and aseptic meningoencephalitis. Acta Paediatr Scand. 1988; 77: 914-915.

4. 渡辺 博, 長谷川毅, 宮沢隆仁. 髄膜炎に対するヴェノ グロブリン髄腔内投与の経験. Medical Postgraduates. 1980; 5: 361-365.

5. Fujiwara S, Muroi K, Tatara R, et al. Intrathecal Administration of High-Titer Cytomegalovirus Immunoglobulin for Cytomegalovirus Meningitis. Case Rep Hematol. 2014; 2014: 272458. doi: $10.1155 / 2014 / 272458$. 


\title{
Efficacy and ploblem of non-complete human immunoglobulin therapy for refractory cytomegaloviral meningo-encephalitis after hematopoietic stem cell transplantation
}

Takashi Onaka, Tomoya Kitagawa, Oju Katayama, Akihito Yonezawa

Department of Hematology, Kokura Memorial Hospital

\begin{abstract}
A 53-year-old female was diagnosed acute type adult T cell lymphoma (ATL). After anti-CCR4 antibody mogamulizmab administration, we performed non-myeloablative cord-blood transplantation. On day 22, GVHD appeared after engraftment. After beginning of PSL, cytomegaloviral (CMV) meningo-encephalitis was occurred. Since the anti-viral drugs were not effective enough, we treated her with intrathecal administration of non-complete human immunoglobulin, which transiently improved her level of consciousness and decreased the CMV viral load. But she died of the refractory CMV encephalitis. Further examination is necessary about intrathecal administration of non-complete human immunoglobulin therapy. (Journal of Hematopoietic Cell Transplantation 6 (4): 162-165, 2017.)
\end{abstract}

